\title{
ESCRIBIR DESDE LA PROSA, LA POESÍA Y LA PINTURA. LOS CUENTOS DE SILVINA OCAMPO
}

\author{
Belén Izaguirre Fernández \\ Universidad de Sevilla \\ belenizaguirre.f@gmail.com
}

Resumen: Al no asumir estrictamente elementos de ninguna escuela ni de ningún género, la prosa de Silvina Ocampo se vuelve híbrida, siempre en constante exploración del límite. En este estudio analizaremos la fluctuación entre lenguajes de diferentes géneros y artes, cuyo resultado son unos textos híbridos que subvierten toda categorización. De hecho, como lectores, dudamos de lo ocurrido. Esto se produce debido a que muchos de los cuentos ocampianos nos plantean la posibilidad de que sean descripciones de sueños y pesadillas, de los delirios y las alucinaciones de un perturbado o que sean recuerdos que se han ido volviendo difusos con el paso del tiempo, permitiendo que la imaginación los modifique. Además, su práctica de diversas formas artísticas crea unos cuentos, o quizás anticuentos, en constante movimiento no solo entre lo real o lo fantástico, sino también entre la prosa, la poesía o la pintura, en un deseo constante de exploración de los límites del lenguaje.

Palabras clave: cuento, literatura argentina, experimentación narrativa, literatura y pintura, transgresión narrativa

\section{WRITE FROM PROSE, POETRY AND PAINTING. SILVINA OCAMPO'S SHORT STORIES}

\begin{abstract}
By not strictly assuming elements of any school or gender, the prose of Silvina Ocampo becomes hybrid, always in constant exploration of the limit. In this paper we will analyse the fluctuation between languages of different genres and arts, the result of which are hybrid texts that subvert all the categorization. In fact, as readers, we doubt about what has happened. This is due to the fact that many of Ocampo's short stories raise the possibility that they are descriptions of dreams and nightmares, the delusions and hallucinations of a disturbed person, or that they are memories that have become diffuse over time as they let the imagination change them. In addition, her practice of various artistic forms created stories, or maybe anti-stories, in constant movement not only between the real and fantastic, but also between prose, poetry or painting, in a permanent desire to explore the limits of language.
\end{abstract}

Keywords: short story, Argentine literature, narrative experimentation, literature and painting, narrative transgression

DOI: https://doi.org/10.24029/lejana.2019.12.378 
Recibido: el 14 de mayo de 2019

Aceptado: el 5 de agosto de 2019

Publicado: el 30 de octubre de 2019 
Los anticuentos se apartan de los cánones establecidos, rompen los moldes y se acercan al amorfismo deliberado en un intento de rebelión y experimentación con las formas y el lenguaje. Muchas de las características de este subgénero han sido definidas por, entre otros, Fernando Melchor o Enrique Anderson Imbert: el final incierto o problemático, la espacialización del tiempo, la desaparición de los personajes tradicionales, la inconformidad ante la realidad circundante, o bien la descripción de lo nimio; todas estas están presentes en la mayor parte de la narrativa de la escritora argentina Silvina Ocampo (1903-1993).

Parte de la escritura de Ocampo se sitúa en un área indeterminada entre la imaginación, la poesía y el relato, un triángulo en cuyo ápice estaría la narrativa, el arte más cultivado, y en su base, la pintura y la poesía en cada vértice, de los cuales se nutriría la primera. Silvina fue antes pintora que narradora, y después poeta. Comenzó a pintar en la infancia, mostrando una tendencia temprana a realizar retratos a sus conocidos. Nunca dejó la pintura totalmente y su parcial abandono de las artes plásticas no impidió que estas fluyeran hasta su escritura. Sus cuentos son mucho más intuitivos que la prosa borgiana o la de Bioy Casares, salvo los incluidos en Autobiografía de Irene (1948), los cuales sí están más cercanos al fantástico tradicional rioplatense y que poco tiene de anticuentos. Es cierto que al resto de su producción los consideramos cuentos estrictamente, pero a veces el lenguaje empleado nos aleja de tal pensamiento, ya que traspasan las fronteras genéricas convirtiéndose en prosa poética. Al respecto, la autora le contestó a Moreno:

- ¿Qué prefiere su poesía o su prosa?

- Creo que son tan diferentes que se equilibran entre sí, hasta podrían matarse por contumacia. Pero escribir poesía me produce casi siempre una especie de empalagamiento intolerable, sin paliativo. En cambio, tengo el hábito resignado de la prosa. Con mi prosa puedo hacer reír. ¿Sería una ilusión? Nunca, ninguna crítica menciona mi humorismo. (Moreno, 2005: 70)

Este rasgo ha sido señalado en varias lecturas críticas, por ejemplo, Maranguello, resalta como "algunos recursos pictóricos son reelaborados en la escritura. [...] Su poética se encuentra atravesada por la impronta de lo visual y el papel que la mirada adquiere en sus relatos es fundamental para comprenderlos" (2012: 1). Esta escritura es resultado de la libertad de creación de nuestra autora. Su escritura se ejerce desde la independencia, fuera de toda imposición genérica o estilística. Tomando la afirmación de Pezzoni, “[e]n Silvina se percibe el constante funcionamiento de una voluntad transgresora de las especificidades genéricas, sea en el ámbito de la poesía o en el del relato" (1999: 14). Algunos de sus cuentos se alejan de toda frontera genérica fijada entre la prosa y la poesía, presentándose como una continuidad entre ambas formas o como un lugar entremedio. Además, aproximándonos a su obra completa, tanto lírica como narrativa, encontramos la enumeración caótica, la sinestesia, la fragmentación, la metonimia, la perspectiva distorsionada, el humor o ficciones que se desenvuelven como una sucesión de metáforas, sin llegar a formar una alegoría sino, más bien, una imagen fragmentada y multiforme. Como señala Ulla, "el riguroso saber del valor de las pausas, demuestran no solo su conocimiento del ejercicio narrativo, sino también del poético" (1997: 29) Y en este sentido se pronuncia Cozarinsky, quien explica que "[c]uando no hay argumento en el sentido convencional, el principio de anécdota es sometido a un tratamiento que, en el ámbito de la ficción, lo desarrolla como una metáfora que podría crecer 
en un poema" (1970: 13). Sus relatos se caracterizan, por tanto, por una hibridez genérica, influenciados posiblemente por el lenguaje fragmentado de la época, los reductos de la vanguardia y su propia trayectoria vital, oscilante entre todas las artes. Asimismo, este rasgo no fue único de su producción, sino que la ruptura genérica y la experimentación lingüística propia del momento se reflejaron en las obras de otros escritores. Como señaló Cortázar,

No existe diferencia genética entre este tipo de cuento y la poesía como la entendemos a partir de Baudelaire [...]. El génesis del cuento y del poema es el mismo, nace de un tiempo en que las etiquetas y los géneros ceden a una estrepitosa bancarrota, no es inútil insistir en esta afinidad que muchos encontraran fantasiosa. Mi experiencia me dice que de alguna manera un cuento breve como los que he tratado de caracterizar no tiene una estructura en prosa. (1969: 42)

Entonces, la poesía, género ambiguo por excelencia, traslada dicha ambigüedad a la prosa poética. Por ejemplo, en Los días de la noche (1970), el cuento “Amnesia” está escrito en verso libre aunque recogido en una obra mayoritariamente en prosa, como también ocurre en otros tantos cuentos de su última obra Cornelia frente al espejo (1988), por ejemplo, en "Arácnidas", "La leyenda del aguaribay", "La begonia chica" y "Los enemigos de los mendigos", todos en verso aunque plenamente narrativos, jugando pues con la forma y el contenido. En estos cuentos en verso, la forma y la experimentación con el lenguaje adquieren mayor importancia, ya que la escritura en verso de cuentos fantásticos no fue frecuente en la postvanguardia. Sin necesidad de recurrir a la versificación, redacta otras historias, siendo una de sus rasgos más visibles la brevedad, influencia surrealista, y la técnica pictórica, que brota especialmente en Viaje olvidado (1937), incluso en los títulos ("Paisaje de trapecio", "Esperanza en flores", "El corredor ancho de sol" o "Cielo de claraboyas"), junto a títulos de obras posteriores, paradójicos y próximos al oxímoron, como "Fragmentos de un libro invisible". Por otra parte, la obra lírica en la que se refleja más la combinación entre poesía y pintura es Espacios métricos (1945), escrita con técnicas de ambas artes.

La pintura es, además, un tema recurrente en sus cuentos: muchos de sus personajes pintan, dibujan y retratan a sus seres queridos. Entre esas narraciones con argumentos vinculados a las artes están "Los retratos apócrifos", La torre sin fin (2007) o "El goce y la penitencia". En este último, la mímesis entre el cuadro y el modelo se logra a la perfección, cumpliendo así uno de los preceptos del arte realista, opuesto al practicado por nuestra autora, que llevado a su última consecuencia adquiere un valor funesto y grotesco: "Cuando mi hijo menor tuvo cinco años, mi marido comprobó que era idéntico al retrato de Santiago" (CC I: 302). La fatalidad llega debido a que la imitación se produce de forma inversa, es el niño el que acaba asemejándose al retrato, argumento similar al de "La lección de dibujo", incluido en Y así sucesivamente (1987).

Uno de los procedimientos en los que la convergencia de estas tres artes es más notable es el gran poder plástico que tienen muchas imágenes, es el caso de "Los amantes" (Las invitadas [1961]), uno de los cuentos más descriptivos de la colección:

Ella abrió el paquete y sacó la bandeja de cartón donde brillaban, un poco aplastados ya, la crema, el merengue y el chocolate. Simultáneamente, como si cada uno proyectara en el otro sus movimientos (¡misterioso y sutil espejo!), tomaron con una mano primeramente, luego con las dos, la tajada de torta con penachos de crema (monumento de los españoles en miniatura), y se la llevaron a la boca. Mascaban al unísono y terminaban de deglutir cada bocado al mismo tiempo. Con idéntica sorprendente armonía se limpiaban los dedos en los papeles que 
otras personas habían dejado tirados sobre el pasto. La repetición de estos movimientos los comunicaba con la eternidad.

Terminada la primera tajada volvieron a contemplar las restantes tajadas en la bandeja de cartón. Con amorosa avidez y con mayor familiaridad tomaron la segunda ración: las tajadas de chocolate, decoradas con merengue. Sin vacilar, con los ojos bizcos, se las llevaron a las bocas desmedidamente abiertas que esperaban. Los pichones abren de igual modo los picos para recibir el alimento que las madres les traen. (CC I: 400)

Se observa aquí el rigor de la descripción, la cual se acerca más a la descripción de un cuadro, a la de una imagen o a la de un guion cinematográfico. Asimismo, esta carece prácticamente de valor en la secuencia narrativa de la acción, la ralentiza y dota al texto, o a estos párrafos, de mayor plasticidad y detallismo, facilitando, por tanto, la inclusión del lector en la escena.

Para la redacción de este y otros cuentos, Ocampo emplea numerosos recursos retóricos, los cuales ya citamos antes, pero no podemos obviar las frecuentes metonimias como uno de sus recursos predilectos, junto a la hipérbole, la enumeración o el oxímoron, tan común en los títulos: Los que aman odian (1946), escrito junto a Adolfo Bioy Casares; Lo amargo por lo dulce (1962) o Los días de la noche (1970). De hecho, esta figura es una de las más afines al género que nos ocupa, ya que es capaz de aunar los contrarios, estos es, los elementos incongruentes que conviven en lo fantástico. Como han visto Fangmann y Ulla, la obra de Silvina Ocampo presenta dificultades para distinguir los límites entre las diferentes discursividades, fruto de su voluntad de transgresión de las reglas genéricas.

Peralta, al hablar de los cuentos de Viaje olvidado, los califica como "una serie de cuadros o acuarelas; relatos en los que lo lírico predomina de tal modo sobre la anécdota que esta se reduce a una mera excusa" (2006: 131). Este carácter poético fue señalado también por Tomassini: "el suceso está subordinado a la visión poética y desconvencionalizada de las cosas" (1995: 379). Por una parte encontramos imágenes influenciadas por el surrealismo y el cubismo, entre las que destacan las descripciones fragmentarias de las que nos ofrece el color, cromatismos disonantes en ocasiones; o la superposición de ciertas perspectivas de un conjunto que resultan en una forma que no tiene por qué encajar con la real o que es poco convencional. El mismo José Bianco nota la influencia surrealista de su primera obra, Viaje olvidado (1988: 148-149), pero no ha sido el único. De igual forma, lo señala Mancini posteriormente, quien ve esta fluctuación entre diversas modalidades artísticas:

La combinatoria de artes a la que recurría en su urgencia para expresarse se traduce en el predominio de las imágenes visuales en sus relatos e indica la apropiación de técnicas y modalidades diferentes que ella combina y rearticula. El resultado es una literatura dúctil y vibrante, una literatura "del dudar del arte", única forma de arte "bueno y genuino", según sostiene Macedonio Fernández en una nota sobre el fenómeno estético que dedica a Silvina Ocampo. (2004: 2)

La propia autora se refirió a este asunto y, gracias a su respuesta, recogida por Ulla, podemos ver como en los inicios de su trabajo artístico se produce esta oscilación de lenguajes que estamos estudiando:

Comencé dibujando. Dibujaba lo que no podía escribir, escribía lo que no podía dibujar. [...] Yo casi toda mi vida la dediqué a la pintura y al dibujo, mi primera infancia, mi adolescencia. Escribí mucho tiempo sin que se enteraran de que yo escribía, algo totalmente informal, libre, ni verso ni prosa, me parecía que no era apto para ser leído o mostrado, hasta que un día empecé a leérselo a alguien. Cuando me di cuenta de que conmovía me lancé a una especie de 
dedicación; en lugar de ponerme a dibujar, me ponía a escribir, pero no había un lenguaje para eso, escribía en inglés, en francés o en español. En este idioma las frases me salían incorrectas y tenía que darles vueltas porque mis lectoras fueron primero inglesas y francesas. Me costó mucho escribir en español, siempre la formación de las frases era en mí incorrecta. (Altamirano y Sarlo, 1982: 285)

A través de esta respuesta podemos deducir que en un primer momento se valió de determinados recursos pictóricos para reelaborarlos en sus primeros escritos. En este sentido es fundamental el papel que adquiere la mirada, sobre todo la de Silvina como narradora, ya que según su perspectiva la descripción puede distorsionarse aún más si cabe. Además, en sus relatos esta mirada para extrañar la realidad se dirige de repente a los pies de un niño, a los cabellos de una señora o a los ruidosos pasos de otro personaje que interrumpe la escena principal. Podríamos equiparar el empleo de esta técnica a la cinematográfica, en la que con cada plano se puede recoger un detalle del entorno, efecto que aquí se logra con cada frase. Asimismo, Ulla ha señalado la aparición de ciertos procedimientos formales relacionados con la estética impresionista (1982a), la cual sería visible, incluso, desde los mismos títulos, por ejemplo, "El corredor ancho de sol", "Cielo de claraboyas" o "Paisaje de trapecios". Sin embargo, no se trata de una transcripción literaria perfecta del expresionismo o del impresionismo, sino de una reelaboración personal, una apropiación de determinados elementos. Así, predominan las descripciones impresionistas, entendiendo esta como aquella que trata de crear una atmósfera subjetiva para lo que se seleccionan unos aspectos y puntos de vista que ofrecen qué ve el autor, cómo lo ve o cómo quiere que lo vean los lectores. Además, la descripción impresionista, como se verá a continuación, tiene como objetivo no tanto definir la realidad con precisión, sino captar su esencia en las sensaciones que producen en el narrador o en los lectores. Por consiguiente, en este tipo de descripción los sentidos entran en contacto con la imaginación. "El corredor ancho de sol" se cierra de la siguiente forma:

Volvió a pensar en el hotel de Francia, porque el linoleum del cuarto de baño del hotel era igual al de aquella casa de campo. Movió blandamente sus grandes brazos de nadadora, y sus manos buscaban un libro sobre la mesa. Hubiera podido nadar, porque nadando se va acostado sobre colchones espesos de agua, y el sol la hubiera sanado, pero los árboles estaban desnudos contra el cielo gris y los toldos de las ventanas volaban el viento. Era inútil que sus manos tomaran el libro. Por la puerta entreabierta se oyeron cantos de cucharas y platos que anunciaban la llegada de una sopa de tapioca en una bandeja con estrellitas y con gusto a infancia. (CC I: 49)

A través de esta descripción observamos la carencia de objetividad. La autora nos ofrece pinceladas de una escena de forma subjetiva al introducir valoraciones y desvíos de la perspectiva. Por ello, destacan los elementos connotativos, estéticos y afectivos que suscita lo descrito, como ese "gusto a infancia" que menciona, es decir, se insertan emociones entre lo escrito y se escribe a partir de las impresiones que el emisor tiene del mundo que describe.

A la hora de acercarnos no solo a la obra sino también a la vida de la argentina, habría que hacerlo teniendo en cuenta las tres disciplinas: prosa, poesía y dibujo. Cuando nos exponemos ante su producción cuentística, hay relatos que parecen componer verbalmente un cuadro o una fotografía, otros están más próximos de lo lírico o podrían reducirse al relato de una imagen uni- o tridimensional. La prosa adquiere carácter pictórico y la brevedad de ciertos relatos supone la escritura o la descripción impresionista de una escena o un personaje, 
el cual puede convertirse en una caricatura, en un esbozo mal trazado que se queda solo con los rasgos más grotescos y llamativos. En Viaje olvidado prima lo poético sobre lo argumental, la prosa toma un carácter pictórico y en ciertos relatos predomina lo poético sobre la prosa, idea que se abandona en la publicación posterior. Por ejemplo, en "La siesta en el centro" podemos rastrear ciertas presencias de la pintura, como la integración de distintas imágenes o la sinestesia que conecta el ruido de las chicharras con las manchas del sol, así, los sonidos intermitentes del insecto se desplazan hacia lo visual, hacia las manchas rojas.

Silvina emplea procedimientos pictóricos de las secuencias descriptivas. Su paso previo por la pintura marcó su carrera y esto se deja ver en alguna de sus descripciones: "Había varios montes color de ciruela en verano y color de oro en el otoño" ("El remanso", CC I: 19), "Cierro las ventanas, aprieto mis ojos y veo azul, verde rojo, amarillo, violeta, blanco, blanco. La espuma blanca, el azul” (“La calle Sarandí”). Esta es más notable en sus primeras incursiones narrativas, posiblemente por su cercanía temporal con su experiencia plástica parisina y bonaerense. De hecho, Valenti recalca como la pintura metafísica de Giorgio de Chirico influyó sobre la autora:

La búsqueda de Silvina Ocampo en el área literaria - así como la de de Chirico en el área figurativa - no se desarrolla sobre la base de experiencia y de las visiones ordinarias que ofrecen una representación puramente convencional de la realidad, sino que aparece dirigida esencialmente a la dimensión más profunda o "metafísica" de la realidad misma: es decir, aquella que vive como "detrás de escena" o "de la otra parte del espejo". (1998: 100)

Esta impronta de lo visual se tematiza en la cuestión de la mirada, en la forma oblicua de mirar que hace que el mundo exterior pierda autenticidad o incremente su plasticidad en el relato. Esto es visible en la importancia del color: "había varios montes color de ciruela en el verano y color de oro en el otoño" ("El remanso", CC I: 19); "Eran tardes frescas y los últimos rayos del sol amarillo, de este mismo rosado-amarillo, envolvía los árboles de la calle Sarandí ("La calle Sarandí", CC I: 55); destaca la presencia del color amarillo en "La red", otro reflejo de su práctica artística, así como el valor de los colores intensos en el sueño; color amarillo que en este relato es símbolo de eternidad, del color de la mariposa y el que deja los rayos lunares al sumergirse en el mar para no volver. Igualmente, reelabora imágenes mediante procedimientos formales de las artes visuales. Por su parte, Maranguello (2013) vincula los versos y las imágenes de los cuentos de Ocampo a la pintura de William Blake, sobre todo en la forma en la que la autora reescribe lo pictórico. Además, la misma crítica intenta demostrar en su estudio que la técnica propia de la mirada pictórica que emplea Silvina irrumpe en "los momentos de mayor intensidad por parte de los personajes, o cuyo recuerdo se imprime de un modo más radical” (Maranguello, 2012), siendo esta más próxima al modernismo y al expresionismo.

La influencia del impresionismo también fue percibida por Ulla (1982a: 37) y por Mancini (2004) en relación a "El pecado mortal", de ahí que la primera observe cierto "tono expresionista". Tenemos que añadir que los vínculos entre la modalidad pictórica del movimiento y la plástica nacen de su origen mismo. Conversando con Ulla, esta comenta: "Precisamente muchos de los nombres de los cuentos de Viaje olvidado tienen una sintaxis o una semántica impresionista: «El corredor ancho del sol», «Cielo de Claraboyas», «Paisaje de trapecios», «La cabeza pegada al vidrio»...”, a lo que Silvina contesta: "Sí, pero después yo rechacé a Renoir, quise reaccionar contra eso y escribí en contra de eso" (1982b: 38). A pesar 
de que afirme un distanciamiento, real pero no total, hubo rasgos del impresionismo que empleó con posterioridad a su primera colección, como los indicados por Óscar Fernández: las ilusiones sensoriales, las sinestesias y cenestesias, y la utilización de correspondencias y de terminología tomada a préstamo de la música y la plástica (1968: 15). La diferenciación entre impresionismo y expresionismo la fija César Aira en su conocido ensayo sobre Roberto Arlt:

[...] en el primero [impresionismo] es el mundo el que viene al artista, en forma de percepciones; en el segundo, el artista da un paso adelante, se coloca a sí mismo dentro de la materia con la que hará su obra. [...] Una vez realizado el salto, el artista se ve en medio de la materia que en términos más prudentes debería haber tratado de ver a distancia, al mínimo de distancia necesario para poder representarla. La ve demasiado cerca, sin perspectiva, la ve en su alrededor, o mejor dicho ya no ve, sino que la toca, en una situación verdaderamente prenatal, se resuelve en ella...

El mundo ha perdido su naturaleza cristalina, se hace gomoso, opaco, de barro. Un mundo de contacto. Y se deforma para hacerle lugar a él, al intruso, se estira, se aplasta, en anamorfosis terroríficas. Obstinado en la inadecuación, el artista se aferra a pesar de todo a los patrones visuales de la representación (no existen otros), y su obra se llena de monstruos. (Aira, 1993: 55-56)

Del mismo modo, los cometarios de Aira sobre Arlt son aplicables a Ocampo. Ya hemos comentado arriba la cuestión de la dirección de la mirada en los fragmentos descriptivos de la autora, pero también tenemos que mencionar cómo muchos de ellos atienden no a lo que ven o escuchan los personajes, sino a lo que sienten, palpan, recuerdan o huelen en un entorno o ante una determinada situación. La descripción parecerá, por tanto, el recuento detallado de un objeto o personaje deformados, aunque en realidad, si tenemos en cuenta las raíces impresionistas e incluso cubistas de la autora, serán una amalgama de puntos de vista, de sensaciones y recuerdos asociados al objeto, pinceladas de color que se fusionan con el fondo de la imagen y con el resto de componentes o elementos de la acción.

Así pues, el abandono de Silvina Ocampo del mundo de la plástica no supuso la eliminación de la mirada pictórica que complejizó la percepción del mundo narrado al incluir la reelaboración de recursos pictóricos aplicados a la escritura, los cuales aumentan la ambigüedad del acto escritural, al mismo tiempo que manipulan los parámetros enunciativos del receptor y del emisor. Lo evocativo predomina sobre lo narrativo, y el receptor se ve forzado a eliminar todas sus consolidadas expectativas sobre el sentido y el significado de lo relatado en un lenguaje que no esperaba en una colección de cuentos. Cornelia frente al espejo contiene cuentos y cuentos con forma de poemas con los que deliberadamente se rompe con la separación genérica y las formas clásicas, además, como señala Roffé, "su anomalía no opera por desconocimiento de las formas literarias, sino por todo lo contrario" (2002: 17).

La disonancia cromática opera en sus descripciones y los colores no tienen por qué responder a los de su referente real. La estética narrativa de Ocampo combina la plasticidad poética y pictórica junto con el poder evocativo del lenguaje. La pintura o el dibujo - incluso el dibujo infantil- se convierte en técnica escritural, sin respetar las reglas de la perspectiva, de la proporción o el color, así, como a nivel narrativo, en el cuento tampoco se respeta la gramática. La ambigüedad es, por tanto, genérica y discursiva, resultado de la creación con elementos constitutivos de diferentes movimientos, artes y géneros. Por ejemplo, el poema 
"La cara apócrifa" en Amarillo Celeste (1972) podría ser leído como un cuento, o "Del diario de Porfiria Bernal", poema, en Espacios métricos (1945) se desarrolla posteriormente en un cuento. Este es, pues, un tema que debemos tratar también como relación intertextual, ya que los temas, los personajes, la forma va de un género a otro, de una forma artística a otra. Klingenberg (2006: 251) señaló dicha vinculación de la literatura con la pintura en la narrativa de Ocampo al mismo tiempo que con lo autobiográfico, de lo que resulta una iconografía muy personal.

Por otro lado, "La fiesta de hielo", incluido en Y así sucesivamente (1987), está escrito en verso por una narradora en primera persona que relata todo lo que ve, por tanto, no hablamos genéricamente de un poema. Hemos dicho ya que en Cornelia frente al espejo aparecen en verso o prosa poética "La alfombra voladora", "Arácnidas", "La begonia chica", "La leyenda del aguaribay" y "Los enemigos de los mendigos". A pesar de todo, no son cuentos en los que se trabaje intencionadamente con la métrica y la retórica. Hay bruscos y repetidos encabalgamientos, no hay rima, ni versos medidos y mucho menos una división estrófica clásica o regular. Tampoco se recurre a rebuscados tropos literarios y, de hecho, sería más una prosa presentada en verso con fines plenamente narrativos, más que lo que consideraríamos lírica como tal. Casualmente o no, los cuentos en verso presentan mayor sencillez y son más fáciles de desentrañar su sentido. Además, incluyen una enseñanza o moraleja final. Por ejemplo, "La begonia chica" y "La leyenda del aguaribay" parecen ser cuentos populares, leyendas o historias míticas o medievales. En el segundo, el árbol americano cobra vida, se desplaza y, como un miembro de la familia más, salva la vida de uno de los niños cuando es necesario, arrancando sus raíces para siempre, hecho que, por cierto, no sorprende ni resulta anormal para nadie.

Por citar algún relato que nos sirva como ejemplo de los diferentes lenguajes que domina Silvina Ocampo, en "La nave", uno de los cuentos finales de Cornelia frente al espejo, encontramos una escritura que da la impresión de ser más automática, que no tiene una planificación previa y trata de reflejar todo cuanto piensa y ve la protagonista en el mágico barco. Todo se va narrando según sucede, sin saltos temporales, espaciales o argumentales, tan solo se intercala algún recuerdo de la protagonista según le surge en su mente, y el único elemento que hilará la narración son las escaleras que no deja nunca de subir y le van trayendo recuerdos a la cabeza:

Tengo hambre, quiero comer. Tengo un sándwich en mi bolsillo. ¿No hay comedor? No hay sala de baile. De qué me acuerdo, si nunca he vivido antes de este momento; momento del tiempo que se aleja. No tengo ningún recuerdo. Se quedó acá. Ya terminé la preparación del viaje. Ahora es el momento más impalpable. Llega el momento de juntar las flores que huyeron de las manos de las personas que dicen adiós. "Vamos a irnos", gritó una nube, que no era una persona. Sigo subiendo la escalera, después otra, después otra, después otra, más frágil, más perfecta; se balancea con el viento. Quiero bajar, quiero visitar los camarotes. "No podemos bajar", dice la escalera más frágil. "¿Y adónde llegaremos?" "Al cielo”, me contestó. La voz de la escalera no temblaba, y me di cuenta de que no tenía miedo. (CC II: 399)

En "La nave", más que hechos, se nos presentan los pensamientos y las divagaciones oníricas y alucinógenas de la protagonista, sobre todo lo que siente en el mar. "La máscara" trabaja con las dudas que invaden a la joven desde el principio de la historia; "El banquete" incluye reflexiones sobre la muerte; en "Ocho alas" el narrador reflexiona sobre un hecho 
pasado que no ha conseguido desvelar con exactitud; en "Soñadora compulsiva" se filtra el lenguaje infantil. En un intento de crear un lenguaje más realista, la narradora de esta última historia nos acerca a su niñez empleando ciertos términos y expresiones impropias de un adulto, por ejemplo, recurre a los superlativos, a los atenuadores; e incluso la perspectiva que se nos ofrece de los hechos es plenamente infantil, se distancia de los adultos y llega a hablar de ellos como "grandes" en lugar de "adultos". Efectivamente, tanto en este como en otros cuentos, la perspectiva ofrecida y el lenguaje empleado difieren según el cuento sea narrado por un niño, un adolescente, un hombre, una mujer o un narrador omnisciente impersonal totalmente ajeno a la historia, evidenciando también las diferencias sociales, de edad o la distancia con respecto a los hechos. Por otra parte, "Color del tiempo" está elaborado con un lenguaje más próximo a la prosa poética cuyas voces buscan crear un ritmo, son inexactas, abstractas, tienen cierta sonoridad, una pausa marcada. La narración se llena de metáforas, paradojas, todo ello para completar esa sinestesia titular de darle un color al tiempo, de ofrecer un canto del ruiseñor perdido:

Me puse mi vestido más precioso azul turquesa, a rayas, con círculos. Me miré en el espejo. Las rayas, contagiadas, aparecieron en mi cara. A pesar de ser bonita, pensé que el color azul turquesa desfigura. Busqué polvos de un rosa pálido y me embadurné la cara y el cuello. Ahora deslumbro a cualquiera. No tengo culpa de ser casi bonita. Tampoco la tendría si fuera fea. No llegué a la edad de las arrugas ni de los pliegues. Ningún papel de seda me envuelve. Es natural. Estoy enamorada: eso reemplaza la belleza. Cuando me miran, tiemblo de amor. No tengo presentimientos, pero aquella noche de fiesta me asusta. Soy capaz de morir en otros brazos, aunque me maten cien veces las alas azules, afiladas. Afuera, oigo cantar un ruiseñor; creo que es un ruiseñor. Trata de deslumbrarme, pero soy fiel a mis principios. Hoy intentaré un poema sin palabras y lo diré, con voz trémula, ante el público, sobre una tarima destartalada, y me desvestiré en el proscenio, con los ojos cerrados. (CC II: 371)

Los cuentos de Silvina no son únicamente narrativos o descriptivos, pues al darles voz a sus personajes, el diálogo se convierte en un recurso necesario y bastante empleado. Aunque en algunos cuentos esté más presente que en otros, es común que entre las intervenciones de los interlocutores se pueda filtrar algo de humor y de ironía, estando más presente aquí que en los fragmentos propiamente narrativos o descriptivos. Por ejemplo, ya hablamos de su presencia en la conversación de Cornelia con sus visitantes, se puede apreciar en los diálogos de "Jardín de Infierno" o "Miren cómo se aman" y, en "El encuentro", la técnica narrativa empleada llega a ser un diálogo continuo con el que no hay que dar explicaciones de todo lo acontecido ni adentrarse en la mente de los interlocutores, debido a que las palabras de los personajes nos informan por sí mismas. En este cuento se le da, además, una curiosa cualidad a las palabras: rellenar el silencio.

En cambio, los cuentos pueden ser también un lugar para la reflexión. Hay casos en los que más que acontecimientos y acciones tenemos una sucesión de reflexiones y pensamientos del narrador. Los personajes se cuestionan a sí mismos, vemos sus inquietudes, sus planteamientos, sus conclusiones. Esto provoca la abundancia de preguntas retóricas. Los narradores cuestionan lo que sucede ante ellos o el porqué de muchas de sus reacciones y comportamientos. Obviamente hay cuentos más reflexivos que otros, ya que en otros relatos hay más diálogo, acción o descripción. Por ejemplo, "El miedo" parece más un ensayo sobre la residencia del miedo o sobre los temores que nos asedian en la vejez que una pieza de ficción. 
En su última colección, Cornelia frente al espejo hay un cuento en particular que trabaja y estudia el tema del lenguaje. "Permiso para hablar" es un breve relato que juega con el lenguaje, su poder y sus límites. En el mundo utópico en el que se desarrolla esta historia parece que se ha establecido una dictadura del lenguaje. Se da permiso para hablar y se ordena el silencio. Se prohíben los llantos, los suspiros. En este maravilloso contexto surge la perfección y se desvela la belleza del mundo antes oculta tras tanto ruido. Entonces las palabras dejan de cumplir su utilidad y surgen otros tipos de lenguajes. La gente se olvida de hablar y cuando se permiten las voces, el ruido es ensordecedor:

Cuando los carteles que indican PERMISO PARA HABLAR dejan lugar a otro, con la palabra SILENCIO, y el silencio baja sobre el mundo con sus alas grises y celeste, un recogimiento dulce invade las casas; las cortinas se abren solas para no hacer ruido, y los niños se visten para ir a la escuela. El piano funciona pianísimo.

El llanto nunca fue considerado como palabra: hubo un conflicto porque nadie se ponía de acuerdo sobre este tema y los que más necesitaban hablar emitían llantos, casi tan incómodos como las palabras. Los prohibieron. Sobrevinieron los suspiros, más flagrantes que las palabras. Los suspiros también lo prohibieron. Entonces el universo en silencio explayó su belleza. (CC II: 359)

Crea Silvina aquí una bella metáfora del lenguaje que nos inquieta ante su realismo y su proximidad. El acto escritural se llena de ambigüedad debido a que Silvina Ocampo jugará con el binomio palabra/imagen. En este ejemplo previo, es la palabra "silencio" la que impone la realidad, es el lenguaje lo que nos condiciona y su más perfecta combinación la que nos suscita y connota imágenes, las cuales son creadas a la perfección por Ocampo, casi con la minuciosidad de la descripción de un escenario de una obra pictórica. De hecho, más tarde recurrirá a la fotografía. La foto en el siglo XX fue una forma artística atractiva para muchos artistas, ya que servía como medio de exploración de la distorsión o de la falsificación producida por una aparente copia de la verdad o realidad, característica que podemos extender a muchos de los cuentos que estudiamos. De este modo, la fotografía supone un encuentro con la ficción, un recreación o una mejora de la realidad hechas con elementos de la realidad misma, afirmación que podemos tomar para la cuentística que ocupa nuestro trabajo. Además de estas técnicas, hay una notable influencia de la pintura en el relieve de descripciones y escenas, y esto puede deberse a que lo pictórico suaviza lo chocante, vuelve más sutil aquello que no debería contarse o que se convierte en chocante o grotesco al hacerlo. Este carácter pictórico de la prosa lo que se percibe desde la primera lectura se logrará a lo largo de su trayectoria de diferentes y dispares maneras.

Por lo tanto, muchos de los cuentos de Ocampo podrían definirse como anticuentos en la medida en que una de las máximas de su escritura fue la transgresión y la rebeldía contra las formas, el lenguaje e, incluso, contra su círculo literario, aunado en torno a la revista Sur. En sus relatos, las imágenes de la memoria se fragmentan, los finales se diluyen, se describe lo intrascendente y la mujer toma la palabra incómoda de recoger en muchos de esos cuentos temas y situaciones a las que no debería haberse ni acercado. Asimismo, el trabajo que realiza Silvina Ocampo con los sueños, la memoria y la autoficción surge de la intención de abrir dudas en los lectores por parte de una escritora interesada en difuminar los límites entre lo ficticio y lo real. Sus cuentos, o anticuentos, se alejan del modo de contar tradicional, apartado de la razón y de la gramática. La mezcla genérica se hará evidente (autoficción, fantasía, 
cuento de hadas, poesía, descripciones, transcripción de sueños, etc.) y desde el inicio al final de la obra de Ocampo se desgranan toda una serie de características de distinta naturaleza.

\section{Bibliografía}

AIRA, César: “Arlt”. Paradoxa. Literatura / Filosofia 7 (1993): 55-71.

ALTAMIRANO, Carlos y Beatriz SARLO (1982): Encuesta a la literatura argentina contemporánea. Buenos Aires, CEAL.

BIANCO José (1988): “Viaje olvidado". En Ficción y reflexión. México, Fondo de Cultura Económica: 148-149.

CORTÁZAR, Julio (1969): "Del cuento breve y sus alrededores". Último round. México, Siglo XXI Editores: 59-81.

COZARINSKY, Edgardo (1970): "Introducción”. En Silvina Ocampo: Informe del Cielo y del Infierno. Caracas, Monte Ávila Editores: 7-17.

FERNÁNDEZ, Óscar (1968): "Notas generales e interdisciplinares sobre el impresionismo". Estudios literarios e interdisciplinarios. La Plata, UNLP, FAHCE: 13-70.

KLINGENBERG, Patricia: “«Literatura como pintura»: Images, Narrative and Autobiography in Silvina Ocampo”. Letras Femeninas XXXII/1 (2006): 251-276.

MANCINI, Adriana (2004): "Silvina Ocampo: la literatura del dudar del arte". En Noé Jitrik (ed.): Historia crítica de la literatura argentina. IX. El oficio se afirma. Buenos Aires, Emecé: 229-251.

MARANGUELLO, Carolina (2012): "Pintar la percepción: la mirada oblicua en algunos relatos de Silvina Ocampo". VIII Congreso Internacional Orbis Tertius y Teoría y Crítica Literaria, Memoria Académica, La Plata, mayo 2012. Disponible en: http://www.memoria.fahce.unlp.edu.ar/trab_eventos/ev.2366/ev.2366.pdf (última consulta el 02/03/2015).

---: "Un abismo radiante: visiones en algunos relatos de Silvina Ocampo". III Congreso Internacional de Cuestiones Críticas, Rosario, abril 2013, disponible en: http://docplayer.es/84379447-Un-abismo-radiante-visiones-alucinatorias-en-algunos-relatosde-silvina-ocampo.html (última consulta el 12/08/2019).

MORENO, María (2005): Vida de vivos. Conversaciones incidentales. Buenos Aires, Editorial Sudamericana.

OCAMPO, Silvina (2006): Cuentos completos I. Buenos Aires, Emecé Editores.

--- (2007): Cuentos completos II. Buenos Aires, Emecé Editores.

PERALTA, Jorge: "Lirismo, autobiografía y autoficción en Viaje olvidado de Silvina Ocampo". Piedra y Canto. Cuadernos del CELIM 11-12 (2005/2006): 131-145.

PEZZONI, Eduardo (1994): "Estudio preliminar". En Silvina Ocampo: Páginas de Silvina Ocampo seleccionadas por la autora. Buenos Aires, Celtia: 13-37. 
ROFFÉ, Reina: “Sabia locura”. Cuadernos Hispanoamericanos 622 (2002): 17-20.

TOMASSINI, Gabriel (1995): El espejo de Cornelia. La obra cuentística de Silvina Ocampo. Buenos Aires, Editorial Plus Ultra.

ULLA, Noemí (1997), "Los caminos de La furia". En Milagros Ezquerro: Aspects du récit fantastique rioplatense. L'Harmattan, París: 10-35.

--- (1982a): Silvina Ocampo. Buenos Aires, Centro Editor de América Latina.

--- (1982b): Encuentros con Silvina Ocampo. Buenos Aires, De Belgrano.

VALENTI, Nora (1988): "Giorgio De Chirico: Huellas de su pintura metafísica en la narrativa de Silvina Ocampo". En María del Carmen Tacconi (coord.): Ficción y discurso. Tucumán, Instituto de Investigaciones Lingüísticas y Literarias Hispanoamericanas. Facultad de Filosofía y Letras, Universidad Nacional de Tucumán: 85-100.

(C) Belén Izaguirre Fernández

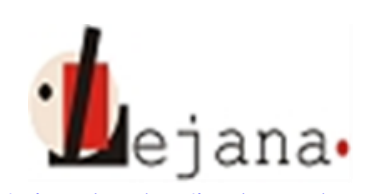

http://ojs.elte.hu/index.php/lejana

Universidad Eötvös Loránd, Departamento de Español, 1088 Budapest, Múzeum krt. 4/C 